\title{
An Approach to Defining the Identity of a Media Fan
}

\section{Javier Lozano Delmar ${ }^{1}$ Juan F. Plaza² \\ Milagrosa Sánchez Martín ${ }^{3}$}

Recibido: 13/02/2019

Aprobado por pares: 30/05/2019
Enviado a pares: 28/02/2019

Aceptado: 10/06/2019

DOI: $10.5294 /$ pacla.2020.23.2.3

Para citar este artículo / to reference this article / para citar este artigo

Lozano, J., Plaza, J. F. \& Sánchez, M. (2020). An approach to defining the identity of a media fan. Palabra Clave, 23(2), e2323. https://doi.org/10.5294/pacla.2020.23.2.3

\section{Abstract}

This study is based on a sample of Spanish viewers of audiovisual fiction, seeking to understand behavior associated with fan identity. A quantitative method was used to explore the characteristics shared by viewers who define themselves as fans, as well as the existence of differences according to various sociodemographic variables. To that end, the Fan Identity Questionnaire was prepared and validated through exploratory and confirmatory factor analysis. The results confirm four types of behavior associated to media fans that, together, can explain and define fan identity with respect to the consumption of media content in Spain: experience, knowledge, collecting, and viewing. The study also shows that those viewers who define themselves as fans obtain higher values in this scale. Taking media fans into account, no significant differences were found in the mean of the Fan Iden-

1 https://orcid.org/0000-0002-0974-1118. Universidad Loyola Andalucía, España. jlozano@uloyola.es

2 https://orcid.org/0000-0002-7741-088X. Universidad Loyola Andalucía, España. jfplaza@uloyola.es

3 https://orcid.org/0000-0002-7387-9971. Universidad Loyola Andalucía, España. msanchez@uloyola.es 
tity Questionnaire based on sex, age, occupation and education and, as a result, we are able to conclude that fan identity is found in the Spanish sample regardless of the above-mentioned sociodemographic characteristics.

\section{Keywords (Source: Unesco Thesaurus)}

Fandom studies; fans; media studies; reception studies; audience studies; validation; questionnaire; fan identity. 


\section{Aproximación a la definición de la identidad del espectador fan}

\section{Resumen}

Este estudio se basa en una muestra española de espectadores de ficciones audiovisuales para intentar comprender los comportamientos que se asocian con la identidad fan. Se utilizó una metodología de carácter cuantitativo con el objetivo de explorar qué características comparten los espectadores que se autodefinen como fans, así como la existencia de diferencias en función de diversas variables sociodemográficas. Para ello, se elaboró y validó, mediante análisis factorial exploratorio y confirmatorio, el Cuestionario de Identidad Fan. Los resultados confirman cuatro comportamientos asociados al espectador fan que, operando de forma conjunta, pueden explicar $y$ definir la identidad fan en el consumo de contenidos audiovisuales de ficción en España: Experiencia, Conocimiento, Coleccionismo y Visionado. Además, el estudio demuestra que aquellos espectadores que se definen a sí mismos como fans obtienen unos valores más altos en esta escala. Teniendo en cuenta a los espectadores fans, no se encontraron diferencias significativas en la media del Cuestionario de Identidad Fan en base al sexo, la edad, la ocupación y el nivel de estudios, por lo que podemos concluir que la identidad fan se observa en la muestra española independientemente de las mencionadas características sociodemográficas.

\section{Palabras clave (Fuente: tesauro de la Unesco)}

Estudios fandom; fans; estudios de televisión y cine; estudios de recepción; estudios de audiencias; validación; cuestionario; identidad fan. 


\section{Abordagem para a definição da identidade de um fã espectador}

\section{Resumo}

Este estudo baseia-se em uma amostra espanhola de espectadores de ficção audiovisual que tem como objetivo tentar compreender os comportamentos associados à identidade dos fãs. Uma metodologia quantitativa foi utilizada para explorar quais são as características dos espectadores que se autodefinem como fãs, bem como a existência de diferenças de acordo com as diversas variáveis sociodemográficas. Para isso, o Questionário de Identidade Fã foi desenvolvido e validado por meio de uma análise fatorial exploratória e confirmatória. Os resultados confirmam quatro comportamentos associados ao espectador fã que, trabalhando juntos, podem explicar e definir a identidade fã no consumo de conteúdo audiovisual fictício na Espanha: experiência, conhecimento, colecionismo e visualização. Além disso, o estudo mostra que os espectadores que se definem a si mesmos como fãs obtêm valores mais altos nessa escala. Levando em conta os espectadores fãs, não foram encontradas diferenças significativas na média do Questionário de Identidade Fã com base no sexo, idade, profissão e nível de estudos; portanto, podemos concluir que a identidade fã é observada na amostra espanhola, independentemente das características sociodemográficas mencionadas.

\section{Palavras-chave (Fuente: tesauro da Unesco)}

Estudos de fandom; fãs; estudos de televisão e cinema; estudos de recepção; estudos de audiência; validação; questionário; identidade fã. 


\section{Introduction}

\section{The difficulty of defining a fan}

Jenkins (1992) was the first to view media fans as active audiences and manipulators of meaning. However, it is difficult to define a fan and to determine when a person is or is not a fan. There are several reasons for this difficulty.

First of all, fan is a commonly used term (Salazar, 2015) that appears frequently in colloquial speech (and therefore, in non-specialized contexts) and has a broad meaning. The Oxford Dictionary of Film Studies defines fandom as "something that typically involves passionate, even obsessive loyalty and attachment to the object of devotion" (Kuhn \& Westwell, 2012, p. 153). Referring to this type of definition, Jenkins (2017) suggests that

Many of these earlier associations persist, shaping what even sym-
pathetic scholars write about fans, resulting in connotations of the
excessive, the obsessive, the delusional, or the religiously devoted.
Yet, at the same time, popular usage of the term has become more
widespread. (p. 65)

In Spanish, the Real Academia Española (RAE) dictionary (2017) defines a fan as an admirer or follower of someone or an enthusiast of something. The Oxford English Dictionary's (2017) definition of the term offers enjoy in addition to the verb admire: "a fan enjoys watching or listening to someone" (Oxford English Dictionary, 2017). However, admire, follow, enthuse and enjoy are terms that do not delimit the meaning of this concept. In fact, according to Duffett (2013), "individual fandom can be conceptualized, partly as a squaring of identities where the potential fan discovers things they like about the text. This squaring can mean a recognition of pleasures, an understanding of creativity, or an appreciation of attitude" (p. 154).

Second, fan has been used to define individuals who differ from one another, i.e., who may share a characteristic but also present divergences: "Fan identity is unlikely to be experienced in the same way by all individuals who identify as fans" (Taylor, 2015, p. 174). In fact, the individuals we 
describe as fans seem to have different levels of involvement, and we suppose a certain gradation in what it means to be a fan. We say that a football team fan is similar to a famous singer or band's fan; however, we also say that people who gather in a community (physical or virtual) to talk about a television series or to create new content based on the plot or the characters of an audio visual product are fans. In the case of sports, being a fan can even lead to violent behavior, and such behavior is not comparable to other manifestations of fan identity. However, recently, a scholar discussion has also arisen about the similarities between fans, anti-fans (defined by their disagreement, dislike or hatred) and toxic fans (characterized by using hate and harassment in his actions). As Gray (2019) points out, fans and anti-fans should both be considered "highly charged viewers (i.e., they care about the text)" (p. 25). According to Guerrero, Establés, and Ventura (2018) "Fan-tagonism may lead to anti-fandom and thus anti-fandom to toxicity" (p. 316). This new approach to fans includes different behaviors and roles that go beyond those that, a priori, were assumed and studied.

\section{For Salazar (2015),}

one of the difficulties in approaching and studying the fan phenomenon is that it is not entirely a coherent and homogeneous object, but, on the contrary, the fandom towards different cultural productions implies diverse activities and occupies different places in the public imagination. (p. 78, our translation)

In a similar way, Booth (cited in Grandío, 2016) notes that fandom is both "more than an identity and more than a behavior" (p. 144). Jenkins (2017), for his part, believes that "where 'fan' once carried some social stig$\mathrm{ma}$, more and more people self-identify as fans, describing a broad range of different relationships with popular media content" (p. 66). In short, as we said, defining what it means to be a fan is a complicated task due to the complexity and variety of the reality it designates.

Finally, while investigating the state of the art in defining the term fan, we find that, in its definition, there are always two different ways of understanding, which in turn involve two dimensions: one of a socio-emotional nature and another that implies a more intellectual one. Ever since Jenkins 
(1992), studies ranging from media and audiences to cultural research have adopted his understanding of a fan as an active viewer (Hills, 2002; Sandvoss, 2005; Sandvoss and Harrington, 2007, 2017; Zubernis \& Larsen, 2012; Hellekson \& Busse, 2014; Grandío, 2016; Alessandrin \& Bourdaa, 2017; Booth, 2018; Click \& Scott, 2018). Other authors from areas more closely linked to the psychology of communication have also developed interest in the importance of community and shared interests between fans (Obst, Zinkiewicz, and Smith, 2001; Tsay-Vogel \& Sanders, 2017).

In general terms, regarding the fans of media products, when someone identifies him- or herself as a fan, he or she transforms consumption into a cognitive-intellectual and socio-emotional adventure. These two components were observed in a study on Spanish fans (Lozano Delmar, Sánchez-Martín, \& Muñiz Velázquez, 2018). It is clear that viewers who define themselves as fans, on the one hand, like series and films that teach them new things, arouse their curiosity, challenge them to continue exploring and learning about the story (for example, through a more active interaction with the content) and make them reflect or adopt a critical stance. This intellectual factor has also been pointed out in studies about the creation of fan fiction linked to active transformative reception by fans (Samutina, 2016). On the other hand, fans prefer films and television series that facilitate collective, participative and social viewing, in which they can analyze and exchange opinions regarding their favorite products. In short, they establish fan communities.

Recently, fan studies have continued to advance in different directions, and some authors have gone as far as to correlate being a fan with being involved in political or social movements (Chin \& Marimoto, 2013) and even with the development of personal qualities such as generosity (Plante, Roberts, Reysen, \& Gerbasi , 2014), although these studies admit methodological weaknesses.

It is important to note that the arrival of social and digital technologies has not changed or transformed the definition and identity of the fan that we want to discuss here: "Rather than exercising entirely new fan practices 
using digital technology, fans today use technology to augment old practices" (Booth \& Kelly, 2013, p. 64). Therefore, it is still very pertinent to consider the first classifications of Fiske (1992) and Abercrombie and Longhurst (1998), who established several categories for measuring audience production and a continuum as a function of their degree of participation. However, although these classifications reflect different types of audiences as a function of their production and activity, we must not forget, as $\mathrm{Zu}$ bernis and Larsen (2012) recall, that the definition and identity of the fans should not be reduced to participation or content creation:

We may value (transgressive) appropriation and transformation over "mere" consumption because, among other things, it provides us with texts, thus overlooking what are perceived to be more "passive" forms of engagement. However, a significant number of fans would define their participations in terms of active consumption of information about their fanned objects. (Zubernis \& Larsen, 2012, p. 16)

In the difficult task of defining what a fan is, self-perception as a fan seems to be a key point. Taylor (2015) explains that fan identity and fan behavior are established by the fans themselves, who explicitly adopt these terms to define themselves. The author also concludes that fan behaviors are more strongly linked to consumption than to production:
Although some fans did report engaging in the creation of fan fiction and engagement with formal fan communities, these were relatively rare. Other types of fan behavior were much more common, even nearly universal, particularly repeated viewing or reading of fan texts and discussing those texts with others. (Taylor, 2015, p. 184)

However, few quantitative studies analyze the identity and behavior of fans of audiovisual fiction, even fewer using validated instruments. As pointed out by Bennet (2018),

\footnotetext{
The use of surveys within fan studies is an important methodological tool, which fosters the ability of a multitude of voices and articulations from fans to be gathered and analyzed. [...] As I have shown and argued, surveys remain a keystone method for fan studies research in that the voices and articulations of fans can be grasped, forming the basis of rich empirical data that is invaluable when discussing fandom. (pp. 36-42)
} 
Several studies with a similar method and subject to the ones proposed in this paper are worth mentioning. Some works use mixed methodologies for the study of audiences, such as the "2003-4 Lord of the Rings International Audience Research Project” by Barker and Mathijs (2012). The work also has a large sampling size. However, it is not appreciated that, during the process of developing the instrument and subsequent data collection, they have gathered evidence regarding validity and reliability.

McCutcheon, Lange, and Houran (2002) made a scale of celebrity fans. Dwyer and Kim (2011), for their part, develop and validate a scale to understand the motivations of fantasy football sports fans. Groene and Hettinger (2016) elaborate a short instrument to analyze the role of identity in media fandom. Obst et al. (2001) came up with a scale to measure the sense of community among fans. Tsay-Vogel and Sanders (2017) study factors such as eudaimonia, identification, and fans in communities. These contributions are valuable because they elaborate instruments to measure elements of fan identity and behavior. Although these scales are applied to fans other than those of audio-visual products, certain scale items can serve as a basis for developing an instrument oriented to fans of such products. However, several studies exhibit methodological limitations during the elaboration and/or validation of these scales, which affect the reliability of their results. Finally, it is interesting to highlight a recent work by Vinney, Dill-Shackleford, Plante, and Bartsch (2019), which aims to develop and validate a measure of popular media fan identity scale. However, this study does not specify certain elements for the factorial analyzes (exploratory and confirmatory) that are essential to determine whether they are correctly executed, such as the normal distribution of the sample, whether the matrix was adequate to factor, and the extraction and rotation factor techniques. Considering the information provided, this instrument cannot be properly assessed as valid and reliable.

The primary objective of this paper is to determine which characteristics and behaviors are shared by users of media products who define themselves as fans in such a way that we can establish a series of questionnaire items that could help define their identity. To this end, we state two 
specific objectives: 1 ) to test and validate characteristics that could potentially define the media fan through a questionnaire developed for that purpose based on the results of a previous qualitative study; and 2) to analyze the socio-demographic characteristics that define the fan and to correlate those characteristics with self-perception as a media fan.

To achieve these objectives, the following research structure is proposed: In the first section, some analyses are performed in order to establish the factorial structure and reliability of the designed questionnaire. In the second section, we perform several descriptive and correlational analyses on the characteristics of the fan.

\section{Method}

\section{Study 1. Questionnaire design and validation: The factorial structure of the Fan Identity Questionnaire}

\section{Participants and procedure}

The data used in this study were collected from a panel of consumers recruited online in 2015. This panel complies with ISO 26362: 2009, quality standard for managing market, opinion and social research and which follows the Privacy Policy for the processing of data in the European Union. A total of 1003 Spanish subjects voluntarily and anonymously completed the questionnaire. The subjects met the inclusion criteria of habitually viewing movies and TV series. The sample of participants was representative of Spanish society and stratified proportionally according to gender and age (i.e., 16-20 years, $20-30$ years and $30-40$ years). The participants were an average age of 27.24 years old $(S D=7.32)$, with the majority $(77 \%)$ having completed higher education or higher-level vocational training. The full sample description can be found in Lozano Delmar, Sánchez-Martín, and Plaza (2015).

The sample was randomly divided into two parts: 481 subjects were used for the exploratory factor analysis (EFA) of the questionnaire, and 522 were used for the confirmatory factor analysis (CFA). 


\section{Measurements}

The initial questionnaire consisted of five items measured on a 7-point Likert scale, with 1 representing complete disagreement and 7 representing complete agreement. The questionnaire was part of a larger study, in which other constructs related to the reception of audio-visual fictions were evaluated with respect to the Spanish viewer.

To design the instrument, the literature on the subject and the previous research of the authors of this study were considered. In this first phase, a scale was constructed based on a previous qualitative study on fans of the Game of Thrones series (HBO, 2011) in France and Spain (Bourdaa \& Lozano-Delmar, 2015). From that study, we obtained a set of five reasons why the respondents considered themselves fans of the series (Bourdaa \& Lozano-Delmar, 2015): 1) Their devotion to the show; 2 ) their experience of the show as something that goes beyond the simple act of reception; 3 ) the urgency in watching every episode; 4) the fact that they collect memorabilia from the show; and 5) the fact they are already a fan of the universe via the books.

The conclusions obtained in that study were similar to those obtained in a subsequent qualitative study on the identity of fans as authors and publicists (who contributed to the promotion of series content). Although, as Hills (2002) notes, "the ethnographic process of 'asking the audience', although useful in many cases, constitutes a potentially reductive approach," (p. 38), these findings are relevant because they link fan identity with the act of seeing and acting in a community (i.e., modes of consumption and viewing, immersing in the content, living it as an experience, and collecting) instead of with the act of creating or producing content (Bourdaa \& Lozano-Delmar, 2016). Table 1 summarizes the five items that composed the initial questionnaire and the key words associated with each.

\section{Table 1. Elements that compose fan identity}

\begin{tabular}{|c|l|}
\hline Key words & \multicolumn{1}{c|}{ Fan identity items in the questionnaire } \\
\hline PLEASURE & $\begin{array}{l}\text { I consider myself a fan of movies or TV series that are well made and developed with interesting } \\
\text { characters and stories that are worthwhile. }\end{array}$ \\
\hline EXPERIENCE & $\begin{array}{l}\text { I consider myself a fan when I get involved in the experience of the movie or television series, look } \\
\text { for additional information on the Internet, participate and generate content on social networks. }\end{array}$ \\
\hline
\end{tabular}




\begin{tabular}{|c|l|}
\hline Key words & \multicolumn{1}{|c|}{ Fan identity items in the questionnaire } \\
\hline VIEWING & $\begin{array}{l}\text { I consider myself a fan when the consumption of a movie or television series is repetitive and } \\
\text { constant, nearly addictive. }\end{array}$ \\
\hline COLLECTING & I consider myself a fan when I collect material related to a movie or television series. \\
\hline KNOWLEDGE & $\begin{array}{l}\text { I consider myself a fan when I like to investigate and know about all the products related to the story } \\
\text { (e.g., sequels, books, and comics). }\end{array}$ \\
\hline
\end{tabular}

Source: Own elaboration.

\section{Statistical analysis}

Exploratory factor analysis (EFA) and reliability. An EFA was performed on one half of the sample with the software Factor 9.2 (Lorenzo-Seva \& Ferrando, 2006) and the unweighted least squares (ULS) extraction technique. This method assumes multivariate non-normality of the data (Bentler, 2005), as verified by the Mardia test (Mardia, 1970) (see the results section). Given that the variables were ordinal (from 1 to 7 ), a polychoric correlation matrix was used. We verified that it provided better results than the Pearson correlation matrix. Although we proceeded from a one-dimensional hypothesis, a two-dimensional result was also investigated using the Promin oblique rotation method (Lorenzo-Seva, 1999).

To verify the validity of the EFA results, the Bartlett's test of sphericity $(\mathrm{p}<0.05)$ and the Kaiser-Meyer-Olkin $(\mathrm{KMO})$ sample adequacy index obtained from the correlation matrix were used. The latter is considered adequate at a value of 0.70 or higher (Costelo \& Osborne, 2005).

To analyze the adequacy of the factorial solution, the following were analyzed: a) residuals, specifically, that the Root Mean Square of Residuals (RMSR) was equal to or less than 0.08 and less than that contributed by the Kelley criterion (Harman, 1962); b) the adjustment indicator of the comparative fit index model (CFI), the only such model that provides polychoric correlations, which was inspected to verify its values were greater than 0.90 ; c) the number of factors obtained and the coherence with parallel analysis (PA) (Timmerman \& Lorenzo-Seva, 2011); and d) the size of the communalities and factorial weights, in which values greater than 0.40 were expected (Bandalos \& Finney, 2010). 
Finally, to verify the internal consistency of the questionnaire, the Cronbach's alpha coefficient was obtained, and each item was discriminated using the corrected element-total correlation. A value of internal consistency equal to or greater than 0.70 was considered adequate (Fornell \& Larcker, 1981; Nunnally \& Bernstein, 1994). Similarly, the corrected element-total correlation of the items must be $\geq 0.35$. If smaller, the item does not adequately discriminate and must be omitted.

Confirmatory factor analysis (CFA). Subsequently, CFA was performed on the other half of the sample using the Mplus v.7 software (Muthén \& Muthén, 2007). The aim was to contrast the validity of the factor structure resulting from the EFA. The method of estimation was robust maximum likelihood, assuming multivariate non-normality of the data, which was verified by the Mardia test (Mardia, 1970). Specifically, if the standardized Mardia value is greater than five (Bentler, 2005), a robust method is used (Satorra \& Bentler, 2001) that corrects the values of the adjustment indices for non-normality.

To assess model fit, the following indicators were considered: the comparative fit index (CFI), the non-normed fit index (NNFI) and the Tucker and Lewis index (TLI). It was verified that these indices had values greater than 0.90 , that the RMSEA was less than 0.08 , and that the test of approximate fit of RMSEA was not significant (Hooper, Coughlan, \& Mullen, 2008).

\section{Study 2. Analysis of factors related to "being a fan"}

\section{Participants and procedure}

Once the factorial structure of the questionnaire and its reliability were verified, we analyzed (for the entire sample) the coherence between the participants who stated that they considered themselves fans (or did not) and the score obtained on the questionnaire. It was hypothesized that those subjects who perceived themselves as fans would score higher than nonfans on the questionnaire.

Subsequently, taking into account the participants who scored the highest on the scale-that is, those who most agreed with the character- 
istics that define the fan, the differences in the total questionnaire scores and in the different items were analyzed according to gender and other socio-demographic variables, such as age, occupation (student, employed, self-employed or unemployed), and education level (compulsory secondary education, vocational education or higher education).

\section{Instruments}

The questionnaire developed and validated in study 1, the Fan Identity Questionnaire (FIQ), was used. The socio-demographic information requested from the participants was used as well as an item included in a broad questionnaire in which the subject was asked to state whether he or she considered him- or herself a fan of any of the proposed productions or of any other ("Do you consider yourself a fan of any fiction?") or, on the contrary, if he or she did not consider him- or herself a fan of any movie or television series.

\section{Statistical analysis}

To analyze the existence of significant differences between the total questionnaire score and the variables to be tested, an analysis comparing the means was performed using Student's t test, analysis of variance (ANOVA) (depending on the number of categories of the grouping variable) or the corresponding non-parametric test (if the assumption of normality was not met). Similarly, when significant differences were found, Cohen's (1992) $d$ was calculated to determine if the magnitude of the differences between the groups was small (0.20), medium (0.50) or large (0.80), according to Lenhard and Lenhard (2016).

\section{Results}

\section{Study 1. Questionnaire design and validation: The factorial structure of the Fan Identity Questionnaire}

\section{Exploratory factor analysis (EFA)}

The data fulfilled all the prerequisites for factorization (Costelo \& Osborne, 2005). Concretely, the value of Kaiser-Meyer-Olkin was acceptable (KMO= $0.79)$, and the Bartlett test of sphericity was not significant $(\mathrm{p} \leq 0.001)$. In addition, we used unweighted least squares (ULS) as an extraction tech- 
nique because of the non-normality of the multivariate distribution (Mardia coefficient=28.88).

To refine the questionnaire and improve the factorial solution, the item "I consider myself a fan of films or TV series that are well made and developed with characters and interesting stories that are worthwhile" (Pleasure) was omitted. This item presented a low factorial loading, $<0.35$ (Bandalos \& Finney, 2010). Once the questionnaire was refined, the average scores of the items ranged from $3.71(\mathrm{SD}=2.06)$ to $4.57(\mathrm{SD}=1.97)$, with the corresponding values of asymmetry $(-0.435,0.125)$ and kurtosis $(-0.994,-1.269)$. There were no outliers.

Following the criteria specified in the "Statistical analysis" section, below we highlight the statistical reasons why the one-factor solution is the best:

- The RMSR was 0.0053 . This value is less than 0.08 and below the expected mean RMSR value for an acceptable model of 0.0456 (Kelley criterion). The adjustment index was also satisfactory ( $\mathrm{CFI}=0.97,>0.08)$.

- Regarding factorial saturation, and as shown in Table 2, all outcomes were greater than 0.60 , ranging between 0.618 and 0.861 .

- The communalities of all the items were greater than 0.40 (from 0.38 to 0.74 ).

- The factor extracted from the EFA explains $69 \%$ of the common variance, a solution confirmed by parallel analysis. The result obtained for internal consistency was satisfactory. Specifically, Cronbach's alpha coefficient was 0.81 , and the discrimination indices of the four items were greater than 0.35 (Table 2).

\section{Table 2. Saturations, communalities, and discrimination of the items}

\begin{tabular}{|c|c|c|c|}
\hline Items & Communalities & Saturations & Discrimination \\
\hline I1. Collecting & 0.544 & 0.738 & 0.599 \\
\hline I2. Experience & 0.742 & 0.861 & 0.688 \\
\hline I3. Knowledge & 0.708 & 0.841 & 0.701 \\
\hline I4. Viewing & 0.383 & 0.618 & 0.522 \\
\hline
\end{tabular}

Source: Own elaboration. 


\section{Confirmatory Factor Analysis (CFA)}

Given the requirement of multivariate normality of the data (Mardia coefficient $=28.88)$, a value greater than 5.00 (Bentler, 2005), it was necessary to use robust estimators.

We can conclude that the one-factor model is acceptable, as noted by the global adjustment indices obtained $(\mathrm{TLI}=0.99$; CFI $=1.00$; RMSEA $=0.028$ with 90\%; $\mathrm{CI}=0.000-0.096 ; \mathrm{RMSEA}<0.05 ; \mathrm{p}=0.607$ ).

Next, Figure 1 presents a diagram of the resulting model, in which the standardized factorial loads are presented with the standard errors of the items. All the calculated parameters were statistically significant $(\mathrm{p}<0.05)$, with values from 0.56 to $0.85(\mathrm{M}=0.75 ; \mathrm{SD}=0.02)$.

\section{Figure 1. Diagram resulting from the CFA, with standardized factor loads}

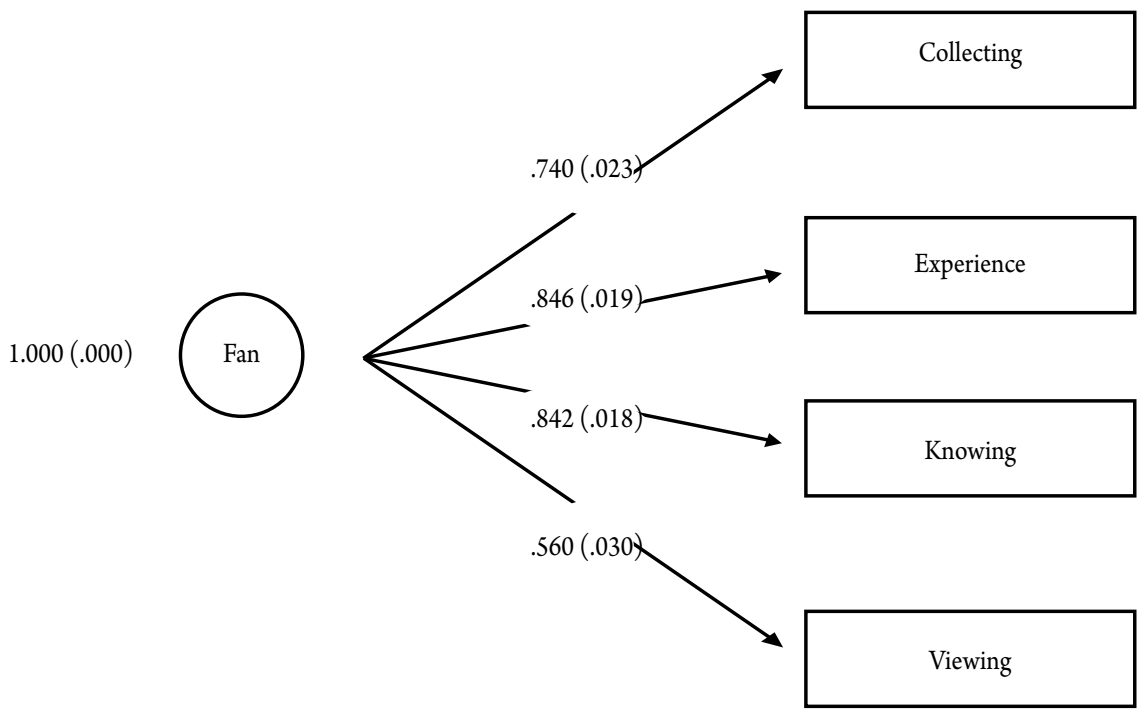

Source: Own elaboration.

Based on the values of saturation, we see that the items that contribute most to defining who a fan is are experience (item $2, \lambda=.846$ ), knowledge (item $3, \lambda=.842$ ), collecting (item $1, \lambda=.740$ ), and viewing (item 4 , $\lambda=.560)$. 


\section{Study 2. Analysis of factors related to "being a fan"}

Once the internal structure of the questionnaire and its consistency were verified, the average of the four items was used to assess the degree to which a spectator defines what it is to be a fan. Taking into account that responses could range from 1 to 7 points, the study participants presented an average of $4.17(\mathrm{SD}=1.58)$.

We analyze the existence of difference in the mean value of the fan scale as a function of a fan's self-perception, gender (men or woman), age range (16-20, 21-30, 31-40 or $>41$ ), occupation (student, employed, self-employed or unemployed), and level of study (compulsory secondary education, vocational education or higher education).

First, we observe that the participants who define themselves as fans exhibit a statistically higher average score on the scale than those who state they are not fans (fans: $M=4.29, S D=1.52$; non-fans: $M=$ $3.42, S D=1.73 ; z=-5.70, p=.000, d=.37$ ). If we consider gender, the differences are manifested in the same way, both for men (fans: $M=$ 4.25, $S D=1.49$; non-fans: $M=3.48, S D=1.87 ; z=-3.19, p=.001, d$ $=.29$ ) and for women (fans: $M=4.33, S D=1.56$; non-fans: $M=3.38$, $S D=1.65 ; z=-4.75, p=0.000, d=0.43$ ). In other words, for both men and women, participants who state that they feel like fans of some type of fiction score significantly higher than those who do not consider themselves fans.

For the following analyzes, we considered 515 participants who presented scores above $50 \%$ of the participants, so we can state that they exemplify the characteristics that define a fan.

Regarding the differences in the items that compose the scale according to gender, we observe that women have higher scores for all variables. However, there are no statistically significant differences between men and women for any of the studied characteristics except viewing (Table 3 ). 


\section{Table 3. Differences in fan characteristics according to gender}

\begin{tabular}{|c|c|c|c|c|c|c|c|}
\hline & \multicolumn{2}{|c|}{$\begin{array}{c}\text { Men } \\
(n=263)\end{array}$} & \multicolumn{2}{|c|}{$\begin{array}{l}\text { Women } \\
(n=252)\end{array}$} & \multirow[t]{2}{*}{$\mathbf{Z}$} & \multirow[t]{2}{*}{$\mathbf{P}$} & \multirow[t]{2}{*}{ dCohen } \\
\hline & M & SD & $\mathbf{M}$ & SD & & & \\
\hline Average fan & 5.38 & 0.81 & 5.50 & 0.89 & -1.33 & 0.182 & 0.117 \\
\hline 1. Collecting & 5.06 & 1.56 & 5.07 & 1.66 & -0.24 & 0.812 & 0.021 \\
\hline 2. Experience & 5.35 & 1.34 & 5.45 & 1.33 & -0.81 & 0.419 & 0.069 \\
\hline 3. Knowledge & 5.59 & 1.10 & 5.69 & 1.23 & -1.51 & 0.131 & 0.128 \\
\hline 4. Viewing & 5.51 & 1.34 & 5.77 & 1.36 & -2.67 & 0.008 & 0.228 \\
\hline
\end{tabular}

${ }^{*} p<.01$.

Source: Own elaboration.

Regarding the differences in the characteristics of a fan according to age range, no statistically significant differences were found for any variable. It seems, therefore, that the youngest and the oldest achieve similar scores on the scale (Table 4).

\section{Table 4. Differences in the characteristics of a fan according to age range}

\begin{tabular}{|c|c|c|c|}
\hline \multirow{2}{*}{ Items } & \multicolumn{3}{|c|}{ Kruskal-Wallis $\mathbf{~}$} \\
\cline { 2 - 4 } & $\mathbf{X}^{2}(\mathbf{2})$ & $\mathbf{P}$ & $\mathbf{d}_{\text {Cohen }}$ \\
\hline Media fan & 1.59 & 0.452 & 0.06 \\
\hline 1. Collecting & 0.04 & 0.983 & 0.12 \\
\hline 2. Experience & 0.31 & 0.856 & 0.12 \\
\hline 3. Knowledge & 0.36 & 0.835 & 0.11 \\
\hline 4. Viewing & 4.23 & 0.121 & 0.13 \\
\hline
\end{tabular}

Source: Own elaboration.

Similarly, statistically significant differences according to occupation were not detected. Students, workers and the unemployed achieved similar levels with respect to the four characteristics of a fan (Table 5). 


\section{Table 5. Differences in fan characteristics according to behavior type}

\begin{tabular}{|c|c|c|c|}
\hline \multirow{2}{*}{ Items } & \multicolumn{3}{|c|}{ Kruskal-Wallis H } \\
\cline { 2 - 4 } & $\mathbf{X}^{2}(\mathbf{3})$ & $\mathbf{P}$ & $\mathbf{d}_{\text {Cohen }}$ \\
\hline Media fan & 3.72 & 0.293 & 0.08 \\
\hline 1. Collecting & 3.78 & 0.286 & 0.08 \\
\hline 2. Experience & 0.56 & 0.905 & 0.14 \\
\hline 3. Knowledge & 0.46 & 0.929 & 0.14 \\
\hline 4. Viewing & 5.69 & 0.128 & 0.15 \\
\hline
\end{tabular}

Source: Own elaboration.

Finally, analyzing the level of education of the participants, we found no statistically significant differences for any fan characteristic among those who had undergone compulsory secondary education (Educación Secundaria Obligatoria - ESO), vocational education (Formación Profesional FP) or higher education (Table 6).

\section{Table 6. Differences in fan characteristics according to education level}

\begin{tabular}{|c|c|c|c|}
\hline \multirow{2}{*}{ Items } & \multicolumn{3}{|c|}{ Kruskal-Wallis H } \\
\cline { 2 - 4 } & $\left.\mathbf{X}^{\mathbf{2}} \mathbf{2}\right)$ & $\mathbf{P}$ & $\mathbf{d}_{\text {Cohen }}$ \\
\hline Media fan & 0.63 & 0.731 & 0.10 \\
\hline 1. Collecting & 0.48 & 0.788 & 0.11 \\
\hline 2. Experience & 0.47 & 0.791 & 0.11 \\
\hline 3. Knowledge & 2.85 & 0.241 & 0.06 \\
\hline 4. Viewing & 0.22 & 0.898 & 0.12 \\
\hline
\end{tabular}

Source: Own elaboration.

\section{Discussion}

In the first section of the research presented in this paper, the FIQ was administered to define fan identity based on a broad and representative sample of Spanish users of audio-visual products.

Of the five items initially proposed (pleasure, experience, viewing, collecting, and knowledge), and based on literature on the subject and a previ- 
ous qualitative study, pleasure was omitted (i.e., "I consider myself a fan of films or TV series that are well made and developed with characters and interesting stories that are worthwhile") because it did not provide a sufficient factorial load in the analysis (>.30).

This item in the questionnaire may have been eliminated because it is an obvious and common characteristic used to designate a media fan and most of the participants stated that they agree with it. A user who is a fan of a film or television series is someone who especially appreciates the quality of the product, likes the stories it develops and how they are told and empathizes strongly with its characters. Duffet (2013) speaks of "recognition of pleasures, an understanding of creativity, or an appreciation of attitude" (p. 154). Therefore, eliminating this item from the questionnaire indicates, above all, that it is an obvious and common characteristic to designate a spectator fan, since most of the participants strongly agree with this item, averaging close to $7(M=5.78, S T=1.50)$, causing the discrimination of the item to be less than 0.35 .

Therefore, collecting, experience, knowledge, and viewing define the identity of a media fan. That is, the identity of a media fan can be explained based on these four different behavioral characteristics. Fan identity in media consumption is a complex construct that includes the four mentioned behavioral characteristics, which operate together.

As was anticipated in the theoretical body, these results suggest an identity that is not linked solely to production, in line with studies proposed by, among many others, Scolari (as cited in Grandío-Pérez, 2016), Zubernis and Larsen (2012), Grandío-Pérez (2016, p. 26) and, most recently, Taylor (2015), as well as the results presented by Tsay-Vogel and Sanders (2017):

our findings reveal that membership in a fan community enhances enjoyment, appreciation, physiological responses, knowledge acquisition, and intention to seek fan-related materials, implying that being a fan entails high degrees of affective, cognitive, and behavioral involvement aside from simply being a passive media consumer. (p. 10) 
As explained by Click, Gray, Mittell, and Scott (2018) during a conversation about the future of fan studies, "I believe it behooves us as scholars to paint 'fan participation' with a broad brush" (p. 437). That is, being a fan does not necessarily involve producing content, as has also been confirmed with this study and the sample of Spanish participants.

Of these four characteristics, the most relevant was experience $(\lambda=$ $.846)$ followed by knowledge $(\lambda=.842)$, collecting $(\lambda=.740)$ and viewing $(\lambda=.560)$. Both experience ("I consider myself a fan when I get involved in the experience of the movie or television series, look for additional information on the Internet, participate and generate content on social networks") and knowledge ("I consider myself a fan when I like to investigate and know about all the products related to the story, such as sequels, books, and comics") make reference to an interest in deepening narratives in an immersive way, with a certain character of discovery, closely connected to the concept of forensic fandom by Jason Mittell (2013) and to drillable texts: "Perhaps we need a different metaphor to describe viewer engagement with narrative complexity. We might think of such programs as drillable rather than spreadable. They encourage a mode of forensic fandom that invites viewers to dig deeper" (para. 3). The user searches for information, participates and discusses with other users, generates content and consumes related content. This also relates to a recent study on digital competencies of the fan: Fans are differentiated from non-fans by digital skills more linked to searching for information and socialization and interaction, than those related to content creation or editing (Herrero-Diz, Lozano Delmar, Del Toro, \& Sánchez-Martín, 2017).

In contrast, collecting refers to the material acquisition of related objects, whereas viewing refers to repetitive, constant and possibly addictive consumption. A recent study on the fan community ("The Ministéricos") of Spanish TV Show El Ministerio del Tiempo [The Ministry of Time] found that $59 \%$ of the viewers returned to watch other episodes (Torregrosa-Carmona \& Rodríguez-Gómez, 2017). A study by Bury (2018) showed that

the majority of fans of popular television can indeed be classified as participatory (...) most are clustered on the "less involved" end of 
the continuum, doing more than viewing a favorite program or series, but not directly engaging in the hallmark practices associated with participatory culture. (p. 126)

\section{The author continues,}

As a first step towards reframing fan studies, I suggest that participation be understood as a continuum: the practices that require the least amount of involvement in participatory culture on the one end, such as information seeking, and those requiring the greatest amount of involvement on the other". (Bury, 2018, p. 125)

In short, considering all the above, a media fan could be defined as a viewer who appreciates (in a broad sense) the content he or she watches and whose admiration is expressed in four equally important behaviors. That is, the fan experiences consuming as an active and participative experience, exploring and learning about the history of the content in the various media forms in which it is spread, collecting related material and frequently viewing the content.

Regarding the second objective of this study, the results confirm that those users who defined themselves as fans achieved a statistically higher average score on the FIQ. Therefore, the self-perception of these viewers coincides with the four behavioral characteristics that define a fan. Those viewers who defined themselves as fans scored higher on the scale than those who did not. Self-definition as a fan is essential because no significant differences were observed among the analyzed socio-demographic variables. This is very important because it underlines the fan identity independent of any of these issues, avoiding the clichés that Jenkins (1992) immediately overturned. That is, the spectator fan is not a young student with much free time on their hands; rather, the fan identity draws on a range of possibilities that could affect any viewer regardless of age, gender, education or occupation.

Our results facilitate new research on the topic of fan identity. One possibility would be to administer the FIQ in other fan communities or in other countries. In this manner, we could investigate the functioning of 
the four defining elements of fan identity in different cultural contexts. Similarly, it would be interesting to delve into each of the elements that compose the questionnaire (collecting, experience, knowledge, and viewing) in a way that the sub-elements that differentiate viewers could be described in more detail according to variables such as the type of fiction of which a person is a fan.

Finally, this study has several limitations that could be overcome in future research. For one, the items should not be understood as the only ones capable of explaining fan identity. Future research can augment the characteristics presented here and enrich the scale. Similarly, this study considers only Spanish fans. However, if the questionnaire is applied elsewhere, it will likely require adjustments to compensate for cultural differences. As Taylor (2015) states, "What exactly constitutes 'fan behavior' is far from a resolved question” (p. 175).

\section{References}

Abercrombie, N., \& Longhurst, B. (1998). Audiences: A sociological theory of performance and imagination. London, UK: Sage Publications.

Alessandrin, A., \& Bourdaa, M. (2017). Fan \& gender studies: La rencontre. Paris, France: Téraèdre.

Bandalos, D. L., \& Finney, J. (2010). Factor analysis: Exploratory and Confirmatory. In G.R. Hancock \& R.O. Mueller (Eds.), Reviewer's guide to quantitative methods (pp. 93-114). New York, NY: Routledge.

Barker, M., \& Mathijs, E. (2012). Researching world audiences: The experience of a complex methodology. Participations. Journal of Audience and Reception Studies, 9(2), pp. 664-689. Retrieved from https:// ueaeprints.uea.ac.uk/id/eprint/40275

Bennet, L. (2018). Surveying fandom. The ethics, design, and use of surveys in fan studies. In M. A. Click \& S. Scott (Eds.), Routledge companion to media fandom (pp. 36-44). New York, NY: Routledge. 
Bentler, P. M. (2005). EQS 6 structural equation program manual. Encino, CA: Multivariate software.

Booth, P., \& Kelly, P. (2013). The changing faces of Doctor Who fandom: New fans, new technologies, old practices? Participations: Journal of Audience \& Reception Studies, 10(01), 56-72. Retrieved from http://www.participations.org/Volume\%2010/Issue\%201/5\%20 Booth\%20\&\%20Kelly\%2010.1.pdf

Booth, P. (2018). A companion to media fandom and fan studies. Chichester, UK: Wiley-Blackwell.

Bourdaa, M., \& Lozano-Delmar, J. (2016). Contemporary participative TV audiences: Identity, authorship and advertising practices between fandom. Participations. Journal of Audience and Reception Studies, 13, 2-13. http://www.participations.org/Volume\%2013/ Issue\%202/2.pdf

Bourdaa, M., \& Lozano-Delmar, J. (2015). Case study of French and Spanish fan reception of Game of Thrones. Transformative Works and Cultures, 19. https://doi.org/10.3983/twc.2015.0608

Bury, R. (2018). "We're not there": Fans, fan studies, and the participatory continuum. In Click, M. A., \& Scott, S., Routledge companion to media fandom (pp. 123-131). New York, NY: Routledge.

Chin, B., \& Morimoto, L. H. (2013). Towards a theory of transcultural fandom. Participations. Journal of Audience \& Reception Studies, 10(1), 92-108. Retrieved from http://www.participations. org/Volume\%2010/Issue\%201/7\%20Chin\%20\&\%20Morimoto\%2010.1.pdf

Cohen, J. (1992). A power primer. Psychological Bulletin, 112(1), pp. 155159. https://doi.org/10.1037/0033-2909.112.1.155 
Click, M. A., Gray, J., Mittell, J., \& Scott, S. (2018). Futures of fan studies: A conversation. In M. A. Click, \& S. Scott, Routledge companion to media fandom (pp. 437-450). New York, NY: Routledge.

Click, M. A., \& Scott, S. (2018). Routledge companion to media fandom. New York, NY: Routledge.

Costelo, A. B., \& Osborne, J.W. (2005). Best practices in exploratory factor analysis: Four recommendations for getting the most from your analysis. Practical Assessment Research \& Evaluation, 10(7), 1-9. Retrieved from https://pareonline.net/pdf/v10n7.pdf

Duffett, M. (2013). Understanding fandom: An introduction to the study of media fan culture. New York, NY: Bloomsbury.

Dwyer, B., \& Kim, Y. (2011). For love or money: Developing and validating a motivational scale for fantasy football participation. Journal of Sport Management, 25, 70-83. https://doi.org/10.1123/ jsm.25.1.70

Fiske, J. (1992). The cultural economy of fandom. In L. A. Lewis (Ed.), The adoring audience: Fan culture and popular media (pp. 30-49). London, UK, \& New York, NY: Routledge.

Fornell, C., \& Larcker, D. F. (1981). Evaluating structural equation models with unobservable variables and measurement error. Journal of Marketing Research, 18(1), 39-50. https://doi.org/10.2307/3151312

Grandío-Pérez, M. (2016). Adictos a las series: 50 años de lecciones de los fans. Barcelona, Spain: UOC.

Gray, J. (2019). How do i dislike thee? Let me count the ways. In M. A. Click (Ed.), Anti-fandom: Dislike and hate in the digital age (pp. 25-41). New York, NY: New York University Press. 
Groene, S. L., \& Hettinger, V. E. (2016). Are you "fan" enough? The role of identity in media fandoms. Psychology of Popular Media Culture, 5(4), 324-339. https://doi.org/10.1037/ppm0000080

Guerrero-Pico, M., Establés, M. J., \& Ventura, R. (2018). Killing off Lexa: "Dead Lesbian Syndrome"' and intra-fandom management of toxic fan practices in an online queer community. Participations. Journal of Audience \& Reception Studies, 15(1), 311-333. Retrieved from: http://www.participations.org/Volume\%2015/Issue\%201/17.pdf

Harman, H. H. (1962). Modern factor analysis. Chicago, IL: University of Chicago Press.

Hellekson, K., \& Busse, K. (2014). The fan fiction studies reader. Iowa City, IA: University of Iowa.

Herrero-Diz, P, Lozano-Delmar, J., Del Toro, A., \& Sánchez-Martín, M. (2017). Estudio de las competencias digitales en el espectador fan español. Palabra Clave, 20(4), 917-947.https://doi.org/10.5294/ pacla.2017.20.4.4

Hills, M. (2002). Fan cultures. London, UK: Routledge.

Hooper, D., Coughlan, J., \& Mullen, M. R. (2008). Structural equation modelling: Guidelines for determining model fit. Electronic Journal of Business Research Methods, 6(1), 53-60. DOI: https://doi. org/10.21427/D7CF7R

Jenkins, H. (1992). Textual poachers: Television fans \& participatory culture. New York, NY: Routledge.

Jenkins, H. (2017). Fan. In L. Ouellette \& J. Gray (Eds.), Keywords for media studies (pp. 65-67). New York, NY: New York University Press.

Kuhn, A., \& Westwell, G. (2012). Dictionary offilm studies (1st Ed.). Hong Kong, Taiwan; Oxford, UK: Oxford University Press. 
Lenhard, W., \& Lenhard, A. (2016). Calculation of effect sizes. Dettelbach, Germany: Psychometrica.

Lorenzo-Seva, U. (1999). Promin: A method for oblique factor rotation. Multivariate Behavioral Research, 34, 347-356. https://doi. org/10.1207/S15327906MBR3403_3

Lorenzo-Seva, U., \& Ferrando, P. J. (2006). FACTOR: A computer program to fit the exploratory factor analysis model. Behavioral Research Methods, Instruments and Computers, 38(1), 88-91. https:// doi.org/10.3758/BF03192753

Lozano-Delmar J., Sánchez-Martín, M., \& Muñiz J. A. (2018). To be a fan is to be happier: Using the eudaimonic spectator questionnaire to measure eudaimonic motivations in Spanish fans. Journal of Happiness Studies, 19(1), 257-276. https://doi.org/10.1007/s10902016-9819-9

Lozano-Delmar, J., Sánchez-Martín, M. \& Plaza, J. F. (2015). Portrait Robot d'un fan Espagnol. Analyse sociodémographique et habitudes de consommation chez le fan de films et de séries télé en Espagne. Revue Française des Sciences de L'information et de la Communication, 7. https://doi.org/10.4000/rfsic.1692

Mardia, K. (1970). Measures of multivariate skewness and kurtosis with applications. Biometrika, 57, 519-530. https://doi. org $/ 10.2307 / 2334770$

McCutcheon, L. E., Lange, R., \& Houran, J. (2002). Conceptualization and measurement of celebrity worship. British Journal of Psychology, 93(1), 67-87. https://doi.org/10.1348/000712602162454

Mittell, J. (2013). Forensic fandom and the drillable text. Retrieved from http://spreadablemedia.org/essays/mittell/\#.WRHgI8m1tBx 
Muthén, L. K., \& Muthén, B. O. (2007). Mplus user's guide. Los Angeles, CA: Muthén \& Muthén.

Nunnally, J. C., \& Bernstein, I. H. (1994). Psychometric theory. New York, NY: McGraw Hill.

Obst, P., Zinkiewicz, L., \& Smith, S.G. (2001). Sense of community in science fiction fandom, Part 1: Understanding sense of community in an international community of interest. Journal of Community Psychology, 30(1), 87-103. https://doi.org/10.1002/jcop.1052

Plante, C., Roberts, S. E., Reysen, S., \& Gerbasi, K. C. (2014). "One of us”: Engagement with fandoms and global citizenship identification. Psychology of Popular Media Culture, 3(1), 49-64. https://doi. org/10.1037/ppm0000008

Real Academia Española. (2017). Fan. Diccionario de la lengua española. Retrieved from http://dle.rae.es/?id=Ha73tO6

Salazar, M. (2015). Las llamaban histéricas: movimiento fan desde una perspectiva de género. Témpora, 18, 75-92. Retrieved from http://riull.ull.es/xmlui/handle/915/4730

Samutina, N. (2016). Fan fiction as world-building: Transformative reception in crossover writing. Continuum: Journal of media \& Cultural Studies, 30(4), 433-450. https://doi.org/10.1080/10304312. 2016.1141863

Sandvoss, C. (2005). Fans: The mirror of consumption. Cambridge, UK/Malden, MA: Polity Press.

Sandvoss, C., Gray, J., \& Harrington, C. L. (2007). Fandom: Identities and communities in a mediated world. New York, NY: New York University Press.

Sandvoss, C., Gray, J., \& Harrington, C. L. (2017). Fandom: Identities and communities in a mediated world ( $2^{\text {nd }}$ ed.). New York, NY: New York University Press. 
Satorra, A., \& Bentler, P. M. (2001). A scaled difference chi-square test statistic for moment structure analysis. Psychometrika, 66, 507-514. https://doi.org/10.1007/BF02296192

Taylor, L. D. (2015). Investigating fans of fictional texts: Fan identity salience, empathy, and transportation. Psychology of Popular Media Culture, 4(2), 172-187. https://doi.org/10.1037/ppm0000028

Oxford English Dictionary. (2017). Fan. Retrieved from https://en.oxforddictionaries.com/definition/fan

Timmerman, M. E., \& Lorenzo-Seva, U. (2011). Dimensionality assessment of ordered polytomous items with parallel analysis. Psychological Methods, 16, 209-220. https://doi.org/10.1037/a0023353

Torregrosa-Carmona, J. F., \& Rodríguez-Gómez, E. (2017). Comunidades de fans y ficción televisiva. Estudio de caso: El ministerio del tiempo (TVE). El profesional de la Información, 26(6), 1139-1148. https://doi.org/10.3145/epi.2017.nov.13

Tsay-Vogel, M., \& Sanders, M. S. (2017). Fandom and the search for meaning: Examining communal involvement with popular media beyond pleasure. Psychology of Popular Media Culture, 6(1), 32-47. https://doi.org/10.1037/ppm0000085

Vinney, C., Dill-Shackleford, K. E., Plante, C. N., \& Bartsch, A. (2019). Development and validation of a measure of popular media fan identity and its relationship to well-being. Psychology of Popular Media Culture. Advance online publication. https://doi.org/10.1037/ ppm0000188

Zubernis, L., \& Larsen, K. (2012). Fandom at the crossroads: Celebration, shame, and fan/producer relationships. Cambridge, UK: Cambridge Scholars Press. 